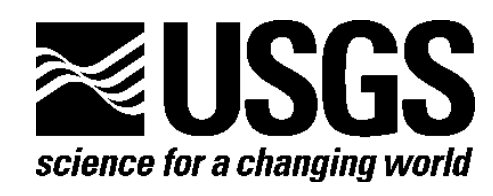

Prepared in cooperation with the Colorado Water Conservation Board

\title{
MODFLOW-CDSS, a Version of MODFLOW-2005 with Modifications for Colorado Decision Support Systems
}

By Edward R. Banta

Open-File Report 2011-1213

U.S. Department of the Interior

U.S. Geological Survey 


\title{
U.S. Department of the Interior \\ KEN SALAZAR, Secretary
}

\author{
U.S. Geological Survey \\ Marcia K. McNutt, Director
}

U.S. Geological Survey, Reston, Virginia: 2011

For product and ordering information:

World Wide Web: http://www.usgs.gov/pubprod

Telephone: 1-888-ASK-USGS

For more information on the USGS - the Federal source for science about the Earth, its natural and living resources, natural hazards, and the environment:

World Wide Web: http://www.usgs.gov

Telephone: 1-888-ASK-USGS

Suggested citation:

Banta, E.R., 2011, MODFLOW-CDSS, a version of MODFLOW-2005 with modifications for Colorado Decision Support Systems: U.S. Geological Survey Open-File Report 2011-1213,19 p.

Any use of trade, product, or firm names is for descriptive purposes only and does not imply endorsement by the U.S. Government. 


\section{Preface}

This report describes MODFLOW-CDSS, a three-dimensional, finite-difference groundwater-modeling program. MODFLOW-CDSS is based on MODFLOW-2005 (Harbaugh, 2005) and includes modifications to fulfill needs identified by the Colorado Water Conservation Board. The modifications include a new Partition Stress Boundaries capability and an option to allow execution to continue when the selected solver fails to converge. The Partition Stress Boundaries capability also supports the Local Grid Refinement (Mehl and Hill, 2005, 2007, 2010) capability.

The performance of the program has been tested in a variety of test simulations. Future uses, however, might reveal errors that were not detected in the test simulations. Users are requested to notify the U.S. Geological Survey of any errors found in this document or the computer program by using the email address available at the Web address below. Updates might occasionally be made to both this document and to the program. Users can download the software or check for updates on the Internet at http://co.water.usgs.gov/projects/modflowcdss/. 


\section{Contents}

Abstract

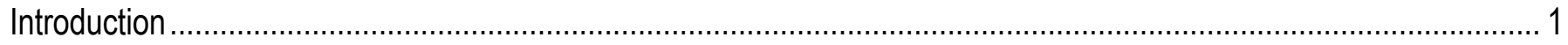

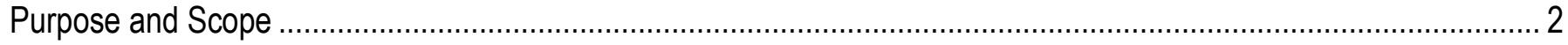

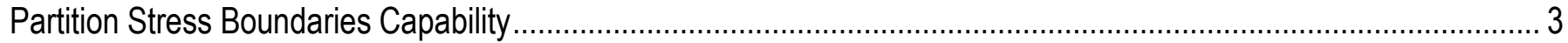

Input Instructions for the Groundwater Flow Process .............................................................................. 4

Input Instructions for the Observation Process...................................................................................... 4

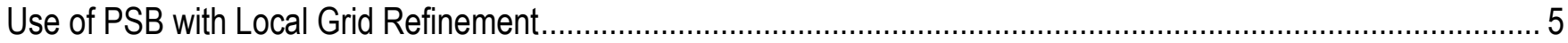

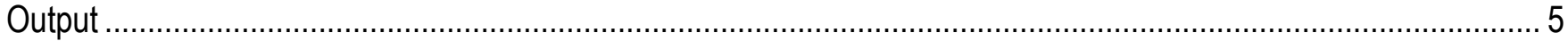

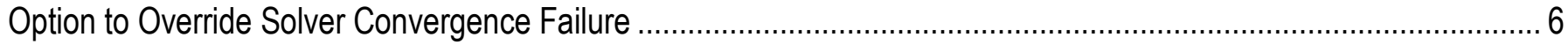

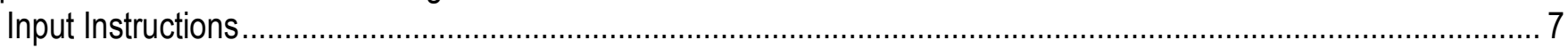

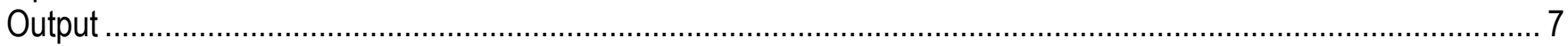

Distribution and Compiling ................................................................................................................

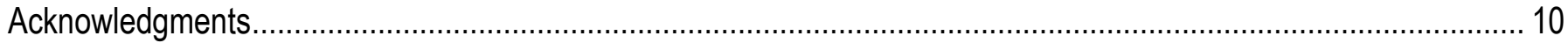

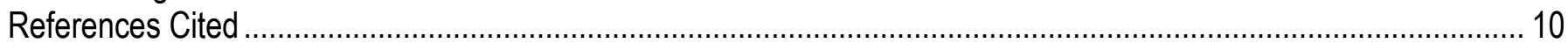

Appendix 1: Programmer Documentation for the Partition Stress Boundaries Capability ......................................... 12

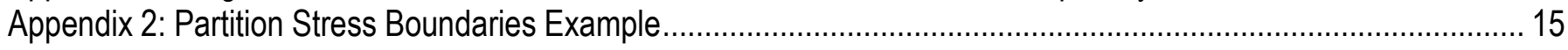

\section{Figures}

1. Excerpt from a name file showing partitions and partition identifiers for Groundwater-Flow-Process input files

2. Excerpt from a name file showing partitions and partition identifiers associating

Observation-Process with Groundwater-Flow-Process input files.

3. Example Basic Package input file showing use of OVERRIDE_CONVERGENCE_FAILURE option.

4. Excerpt from MODFLOW-CDSS listing file showing output generated when convergence failure is overridden.

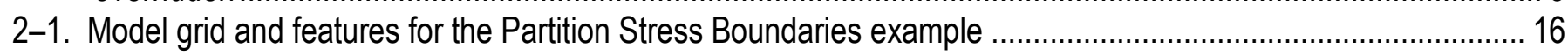

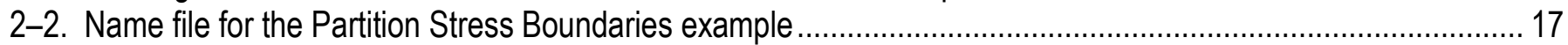

2-3. Selected output for the Partition Stress Boundaries example ................................................................. 18

2-4. Volumetric flow rates for water-budget components of the Partition Stress Boundaries example...................... 19

\section{Tables}

1. Packages and file types supported by the Partition Stress Boundaries capability ……....................................... 3

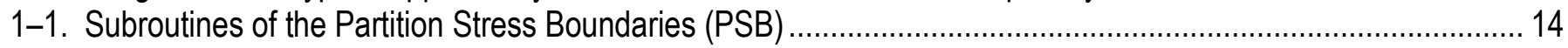




\section{Abbreviations}

CDSS Colorado Decision Support Systems

CWCB Colorado Water Conservation Board

ET Evapotranspiration

GMG Geometric Multigrid Solver

GWF Groundwater Flow (Process)

LGR Local Grid Refinement

PSB Partition Stress Boundaries

URL Universal Resource Locator 


\title{
MODFLOW-CDSS, a Version of MODFLOW-2005 with Modifications for Colorado Decision Support Systems
}

\author{
By Edward R. Banta
}

\begin{abstract}
MODFLOW-CDSS is a three-dimensional, finite-difference groundwater-flow model based on MODFLOW-2005, with two modifications. The first modification is the introduction of a Partition Stress Boundaries capability, which enables the user to partition a selected subset of MODFLOW's stress-boundary packages, with each partition defined by a separate input file. Volumetric water-budget components of each partition are tracked and listed separately in the volumetric water-budget tables.

The second modification enables the user to specify that execution of a simulation should continue despite failure of the solver to satisfy convergence criteria. This modification is particularly intended to be used in conjunction with automated model-analysis software; its use is not recommended for other purposes.
\end{abstract}

\section{Introduction}

This report documents MODFLOW-CDSS, a three-dimensional, finite-difference groundwater-flow model application based on MODFLOW-2005 (Harbaugh, 2005) with modifications designed to support needs related to development of groundwater models for Colorado's Decision Support Systems (CDSS) (Colorado Water Conservation Board and Colorado Division of Water Resources, 2005). One need is to be able to enter and separately track components of stresses on a groundwater system when the components are to be simulated using the same MODFLOW-2005 package. A common approach in this situation is to modify the MODFLOW (MODFLOW-2005 or earlier version) source code to add one or more essentially identical copies of one (or more) of MODFLOW's packages; this approach was used, for example, by Danskin and others (2006) to track multiple components of recharge and of pumping from wells. When this approach is used, the source code needs to be modified and recompiled to accommodate each new stress component. A more convenient approach would be to develop a capability to allow simulated stresses to be partitioned as desired by the modeler without requiring additional revisions to the source code. A second need relates to an ability to make repeated MODFLOW simulations during automated parameter estimation, during which a large number of simulations are run with a potentially widely varying set of model-input, or parameter, values. In this situation, model convergence can be difficult to obtain for all parameter sets generated during parameter estimation. An option to override convergence failure, designed to be used in automated parameter estimation, would be a valuable addition to MODFLOW.

To address these needs, MODFLOW-CDSS includes two modifications: (1) a Partition Stress Boundaries (PSB) capability and (2) an option to override solver convergence failure and to 
continue execution. The first modification allows the partitioning of simulated stresses by separating input of any of the supported packages into multiple input files, where each input file defines a partition. The second modification is designed to facilitate automated parameter estimation by allowing execution to continue when solver closure criteria are not met for one or more time steps.

\section{Purpose and Scope}

In 2008, the Colorado Water Conservation Board (CWCB) identified two needs related to the use of MODFLOW-2005 (Harbaugh, 2005) in groundwater-modeling components of CDSS. The first was a need to categorize and track components of various types of stresses on aquifers; the second was a need to enable MODFLOW-2005 to continue execution despite solver nonconvergence when model runs are executed by automated model-analysis software.

In MODFLOW-2005, a variety of Packages (for example, the River, Drain, Recharge, and Evapotranspiration Packages) can be used to define various types of boundary conditions in the finite-difference system of equations that is set up to simulate the flow of groundwater in an aquifer system. In the original MODFLOW-2005 software, all input for boundaries of a given type of stress was specified in a single input file. For example, input for all river boundaries would be specified in a single River-Package input file. Output from a MODFLOW-2005 run would then include one or more volumetric water-budget tables in which all River-Package stresses would be summarized, with one entry that would include all river flow into the groundwater system and one entry for all river flow out of the groundwater system. The CWCB identified a need to categorize and track user-specified components of each stress package to facilitate interpretation of model stresses and water-budget components. The PSB capability described in this report addresses this need.

When performing various automated model analyses (for example, parameter estimation) a large number of model simulations are commonly required to obtain desired results. During the course of an analysis, numeric parameter (model-input) values are manipulated, the model is executed, and model results are analyzed, often in an iterative fashion. Parameter values may vary widely during the analysis. It can be difficult to assign values to variables that control solver performance in a way that will enable the solver to reach convergence in a reasonable amount of computational time for all parameter sets that are used in an analysis. In the original version of MODFLOW-2005, execution stops if convergence is not achieved at a time step. Model-analysis programs generally are not designed to handle situations where the simulation does not run to completion. Precise model results are generally desirable throughout the course of parameter estimation by nonlinear regression (Yager, 2004). However, depending on solver convergence criteria and individual model setup, model results that are sufficiently precise for early parameterestimation iterations may be obtained even when solver convergence is not achieved. One way to evaluate the precision of model results in the absence of solver convergence is to look at the error listed at the end of the volumetric water-budget table for each time step. In particular, achieving solver convergence is likely to be less important during early and intermediate parameterestimation iterations than it is during the final iterations of a parameter-estimation analysis. An option to override solver convergence failure and continue execution was implemented to address this issue. It is important to recognize the potential for production of highly inaccurate model results when this option is used, and to avoid its use in any situation in which accurate model results are needed. 
The PSB capability was implemented in two programs, MODFLOW-CDSS and MODFLOW-LGR-CDSS, which are available at the URL listed in the Preface of this report. MODFLOW-CDSS also supports the option to override solver convergence failure. MODFLOWLGR-CDSS implements Local Grid Refinement (LGR; Mehl and Hill, 2005, 2007, 2010).

\section{Partition Stress Boundaries Capability}

When modeling groundwater flow in regional aquifer systems, modelers are often confronted with a need to track components of the water budget in greater detail than is provided by the set of stress-boundary packages of MODFLOW-2005. For example, it may be desired to distinguish between the evapotranspiration (ET) rates of different vegetation types which have different ET extinction depths. In this situation MODFLOW-2005 does not make it easy for the modeler to distinguish between the simulated ET rates of a variety of vegetation types. The Riparian evapotranspiration (RIP-ET) methodology (Maddock and Baird, 2002; Baird and Maddock, 2005) provides this and more sophisticated capabilities for simulating ET in riparian areas, but it does not address stresses other than ET. In other situations, modelers and waterresources managers may find it convenient to track water-budget components within MODFLOW as an alternative to writing project-specific pre- and postprocessor utilities for manipulating model input and analyzing model output.

The PSB capability was developed to allow modelers to partition model input to identify and track components of stresses with a degree of detail greater than that of the package-based categorization of MODFLOW-2005. When a stress package is partitioned using PSB, partitions are defined by the use of multiple input files for supported packages. For example, users may find it advantageous to use PSB to track different sources of recharge, different components of ET, or pumping rates for different categories of wells. The PSB capability supports partitioning in the packages listed in table 1. Another potential use of PSB would be to simplify the task of activating or deactivating simulation of specific components of stresses. If partitions are suitably defined, only the name file would need to be edited to activate or deactivate a selected component.

Table 1. Packages and file types supported by the Partition Stress Boundaries capability.

\begin{tabular}{|c|c|c|}
\hline Package Name & File Type for Name File & Reference \\
\hline & \multicolumn{2}{|l|}{ Groundwater Flow Process } \\
\hline Drain Package & DRN & Harbaugh (2005) \\
\hline Drain Return Package & DRT & Banta (2000) \\
\hline Evapotranspiration Package & EVT & Harbaugh (2005) \\
\hline Evapotranspiration Segments Package & ETS & Banta (2000) \\
\hline General Head Boundary Package & GHB & Harbaugh (2005) \\
\hline Recharge Package & $\mathrm{RCH}$ & Harbaugh (2005) \\
\hline River Package & RIV & Harbaugh (2005) \\
\hline \multirow[t]{2}{*}{ Well Package } & WEL & Harbaugh (2005) \\
\hline & Observation Process & \\
\hline Drain Package & DROB & Harbaugh and Hill (2009) \\
\hline General Head Boundary Package & GBOB & Harbaugh and Hill (2009) \\
\hline River Package & RVOB & Harbaugh and Hill (2009) \\
\hline
\end{tabular}




\section{Input Instructions for the Groundwater Flow Process}

The PSB capability of MODFLOW-CDSS is invoked by entering any of the file types listed in table 1 in a MODFLOW-CDSS name file multiple times. Each entry should identify an input file appropriately prepared for the associated package; no modifications to stress-package input files are required to make use of the PSB capability. Each entry of a Groundwater Flow (GWF) Process file type listed multiple times will be treated as a partition of the corresponding package. Each partition can be identified by a partition identifier (a text string of 1 to 16 characters) following the file name in the name file. The 16-character limit allows the partition identifier to be listed in its entirety in the volumetric water-budget tables. The identifier also is written to the binary cell-by-cell flow file(s) (Harbaugh, 2005) in the position occupied by the 16-character TEXT variable. If a file type is listed only once, it is handled by the corresponding package, not by PSB. An example excerpt from a name file is shown in figure 1.

\begin{tabular}{|llll|}
\hline$\ldots$ & & & \\
RIV & 21 & Allegheny.riv & Allegheny \\
RIV & 22 & Monongahela.riv & Monongahela \\
RIV & 23 & Ohio.riv & "Ohio_River" \\
RCH & 24 & precip.rch & Precip_RCH \\
RCH & 25 & irrig.rch & Irrig_RCH \\
$\ldots$ & & & \\
\hline
\end{tabular}

Figure 1. Excerpt from a name file showing partitions and partition identifiers for Groundwater-Flow-Process input files.

In this example, these entries would cause PSB to create three River-Package partitions and two Recharge-Package partitions. The River-Package partitions would be labeled in the volumetric water-budget tables and cell-by-cell flow file(s) with the partition identifiers "Allegheny," "Monongahela," and "Ohio River." Note the (required) use of quotation marks in the name file to specify a partition identifier with an embedded space character. Similarly, the Recharge-Package partitions would be labeled "Precip_RCH" and "Irrig_RCH."

\section{Input Instructions for the Observation Process}

When flow observations are specified for packages that are partitioned using PSB, observations must be specified in files that correspond to the partitions defined by the GWF-Process input files. The partition identifier used for each partition is then also used with the appropriate ObservationProcess input file to enable PSB to associate observations with the correct partition. The association is based on a case-insensitive match between partition identifiers listed for the Observation-Process input file and for the GWF-Process input file. Like partition identifiers for GWF-Process files, partition identifiers for Observation-Process input files need to be from 1 to 16 characters in length. When the Observation Process is used with a partitioned stress package, the partition identifier for each GWF-Process input file needs to be unique among partition identifiers for all GWF-Process input files for that stress package; this requirement ensures correct association between each Observation-Process input file and its corresponding GWF-Process input file. 
Observation-Process input files are prepared as described in Harbaugh and Hill (2009). Figure 2 illustrates the use of partition identifiers to associate Observation-Process input files for RiverPackage observations with River-Package partitions of the Groundwater Flow Process. Definition of observations based on stress boundaries included in multiple partitions is not supported. This restriction means, for example, that the Observation Process cannot be used to define a flow observation based on a set of river cells where some river cells in the set are defined in Allegheny.riv and other river cells in the set are defined in Ohio.riv (fig. 2).

\begin{tabular}{|llll|}
\hline ... & & & \\
RIV & 21 & Allegheny.riv & Allegheny \\
RIV & 22 & Monongahela.riv & Monongahela \\
RIV & 23 & Ohio.riv & "Ohio River" \\
RVOB & 31 & Allegheny.rvob & Allegheny \\
RVOB & 32 & Monongahela.rvob & Monongahela \\
RVOB & 33 & Ohio.rvob & "Ohio River" \\
$\ldots$ & & & \\
\hline
\end{tabular}

Figure 2. Excerpt from a name file showing partitions and partition identifiers associating ObservationProcess with Groundwater-Flow-Process input files.

\section{Use of PSB with Local Grid Refinement}

The program MODFLOW-LGR-CDSS, which is provided in the distribution file at the URL listed in the Preface of this report, supports both LGR (Mehl and Hill, 2005, 2007, 2010) and PSB. PSB is activated in MODFLOW-LGR-CDSS the same way it is activated in MODFLOWCDSS: by listing multiple input files for supported stress packages in the name file(s) (figs. 1 and 2) listed in an LGR control file. PSB can be activated in any combination of parent and child grids. Partition identifiers for each grid are internally treated as being independent of partition identifiers for all other grids. As a result, partition identifiers may be reused in different grids, if desired. Another result is that partitions for Observation-Process files can only be matched with partitions for GWF-Process files listed in the name file for the same grid.

\section{Output}

When PSB is activated by inclusion of multiple GWF-Process input files with a given stress-boundary type in the name file, PSB writes a message to the listing file. The message indicates that PSB has been activated and includes a table showing the package, unit number, partition identifier, and input file associated with each partition. The unit numbers in this table can be used to associate partitions with output generated by the "Allocate and Read" procedure of the stress packages for each input file. Each volumetric water-budget table lists entries for each partition. Also, the cell-by-cell flow files referenced in stress-package input (for example, IRIVCB of the River Package) will have partition identifiers in place of the default identifier associated with the stress package. For example, if River-Package output is to be written to a cell-by-cell flow file for the three River Package partitions in the example above to one cell-by-cell flow file, the file will have multiple River-Package entries for each time step for which output is requested. Instead 
of one entry with the identifier "RIVER LEAKAGE," the file will contain three entries with identifiers "Allegheny," "Monongahela," and "Ohio River." For this reason, post-processing programs that rely on the original values of the TEXT identifiers in the cell-by-cell flow file for analytical or reporting purposes may need to be modified to handle a cell-by-cell flow file containing variable TEXT identifiers written by MODFLOW-CDSS for different partitions. Zonebudget (Harbaugh, 1990), a program for calculating zone-based water budgets using results from MODFLOW, does not rely on the original identifiers; instead, it identifies water-budget components by the 16-character TEXT identifiers read from the cell-by-cell flow files. Therefore, Zonebudget requires no modification to work with a cell-by-cell flow file generated by MODFLOW-CDSS. Similarly, GW_Chart (Winston, 2000), a program for graphical analysis of model output, identifies water-budget components and requires no modification to work with output generated by MODFLOW-CDSS. When either GW_Chart or Zonebudget reads data from a cell-by-cell flow file containing partitions, water-budget components are identified in output by partition identifier. As is the case when either Zonebudget or GW_Chart is used with MODFLOWLGR (Mehl and Hill, 2005, 2007, 2010), a separate analysis is required for each parent or child grid for which a zone-based or graphical water-budget analysis is desired for a MODFLOW-LGRCDSS simulation.

\section{Option to Override Solver Convergence Failure}

When a large number of model runs are to be made by an automated model-analysis program, in which parameter (model-input) values may vary widely, difficulty may be encountered in determining solver input that will consistently achieve convergence for all model time steps in an acceptable execution time. This problem is addressed by MODFLOW-2000 (Harbaugh and others, 2000; Hill and others, 2000), which, when used in parameter-estimation mode, does not stop execution on solver nonconvergence. Doherty (2010) suggests modifying a model's source code to read closure criteria from a separate file and then using a batch file to rewrite this file with increased closure criteria and repeat execution of the model if a model run fails to converge. When performing parameter estimation using UCODE_2005 (Poeter and others, 2005) or PEST (Doherty, 2010), for early parameter-estimation iterations, acceptable progress in the parameter-estimation process often can be obtained even if the groundwater-flow equation solver does not achieve convergence. This is the situation for which the option to override convergence failure is designed; the use of this option for other purposes is not encouraged. Users are reminded that calculated head values likely are not accurate within the head-closure criterion specified in solver input when closure criteria are overridden. Errors in calculated head also can result in errors in other quantities that depend on accurate head values. In particular, values of groundwater flow are dependent on calculated head values and will be in error if the head values are in error. Similarly, other simulated processes that depend on calculated heads, for example, particle tracking for advective transport, will be in error if the head values are in error.

When the option to override solver convergence failure is invoked, acceptability of the approximated solution of the groundwater-flow equation is the user's responsibility. When convergence failure is overridden at one or more time steps, a summary of convergence failures is written at the bottom of the listing file and provides a convenient way to quickly evaluate the degree to which convergence failure affects the volumetric water-budget balance. For each time step where convergence failure is overridden, the summary lists the percent discrepancy of the volumetric water-budget flow rates. These are the rate discrepancies calculated at each time step 
and printed at the bottom of the "rates for this time step" column of each volumetric water-budget table.

The OVERRIDE_CONVERGENCE_FAILURE option can be used regardless of the solver selected to solve the groundwater-flow equation. Convergence-failure override is independent of the logic an individual solver uses to determine convergence.

MODFLOW-LGR (Mehl and Hill, 2005, 2007, 2010) is programmed such that, when a simulation includes one or more child models, execution continues even if the solver does not reach convergence for the parent model or any child model, or if LGR iterations fail to converge in the specified number of iterations. MODFLOW-LGR-CDSS preserves this behavior. For this reason an option to override solver convergence failure is not needed in MODFLOW-LGR-CDSS. Note that if MODFLOW-LGR-CDSS is used to simulate a system that contains no child models, execution will stop if the solver fails to converge.

\section{Input Instructions}

The option to override solver convergence failure is activated by entering "OVERRIDE_CONVERGENCE_FAILURE" in item 1 (Options) of the Basic Package input file (fig. 3). All other input is prepared as documented in Harbaugh (2005).

\begin{tabular}{|lcll}
\hline \multicolumn{2}{l}{ FREE SHOWPROGRESS } & OVERRIDE_CONVERGENCE_FAILURE & Item 1: options \\
CONSTANT & 1 & Item 2: IBOUND, layer 1 \\
CONSTANT & 1 & Item 2: IBOUND, layer 2 \\
CONSTANT & 1 & Item 2: IBOUND, layer 3 \\
-999.9 & & Item 3: HNOFLO \\
CONSTANT & 100.0 & Item 4: STRT, layer 1 \\
CONSTANT & 100.0 & Item 4: STRT, layer 2 \\
CONSTANT & 100.0 & Item 4: STRT, layer 3 \\
\hline
\end{tabular}

Figure 3. Example Basic Package input file showing use of OVERRIDE_CONVERGENCE_FAILURE option.

\section{Output}

When OVERRIDE_CONVERGENCE_FAILURE is specified in Basic Package input as described above, a message is written to the listing file indicating that the OVERRIDE_CONVERGENCE_FAILURE option has been selected. If convergence is achieved for all time steps, no other output related to this option is generated.

When OVERRIDE_CONVERGENCE_FAILURE is specified and solver convergence fails for one or more time steps, additional output is written to the listing file and to the screen. For each time step for which solver convergence fails and execution is allowed to continue, a warning message is written to the listing file indicating the time step and stress period in which convergence failed. In addition, at the bottom of the listing file, a summary of convergence failures is written, showing the stress period, time step, and percent discrepancy of flow rates for the volumetric water budget at the indicated time step. The summary of convergence failures is followed by a warning message noting the number of time steps for which solver convergence failed (fig. 4). A brief 
warning message showing the number of time steps for which solver convergence failed also is written to the screen.

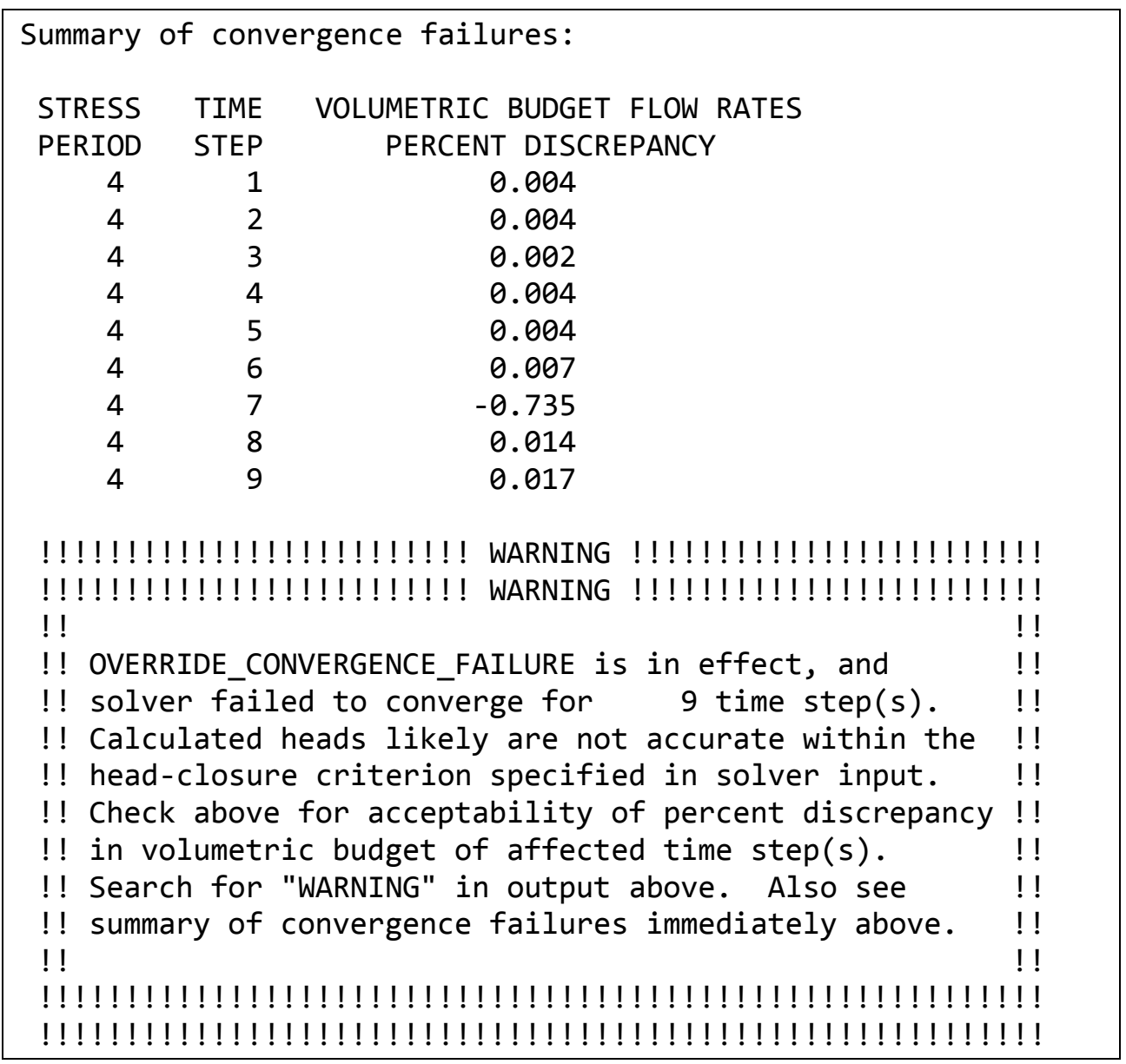

Figure 4. Excerpt from MODFLOW-CDSS listing file showing output generated when convergence failure is overridden. 


\section{Distribution and Compiling}

The compressed distribution file available for download from the URL listed in the Preface of this report contains executable files, source-code files, documentation, and input and output files for two example problems. When extracted, the distribution file generates several directories, organized as follows:

\begin{tabular}{|l|}
\hline modflow-cdss \\
bin \\
doc \\
src \\
mf2005_cdss \\
mflgr_cdss \\
test-out \\
psb \\
tc1huf_ncnvg \\
test-run \\
psb \\
tc1huf_ncnvg \\
\hline
\end{tabular}

The "bin" directory contains the executable files for MODFLOW-CDSS (mf2005_cdss.exe) and MODFLOW-LGR-CDSS (mflgr_cdss.exe). The "doc" directory contains documentation file(s). Each subdirectory under the "test-run" directory contains a batch file and input files required to run one example simulation. The "psb" subdirectory contains files for the Partition Stress Boundaries example presented in Appendix 2. The "tc1huf_ncnvg" subdirectory contains files that demonstrate the use of the OVERRIDE_CONVERGENCE_FAILURE option. Output files for each example simulation are in corresponding subdirectories under the "test-out" directory. When run, the example problems write output files into subdirectories of the test-run directory; the output files can be compared with the files distributed in the corresponding subdirectories of the test-out directory to demonstrate that the programs function as intended.

The "src" directory contains two subdirectories: "mf2005_cdss" contains all source code needed to compile MODFLOW-CDSS, and "mflgr_cdss" contains all source code needed for MODFLOW-LGR-CDSS. These subdirectories contain both Fortran source-code files (with extensions "f" and "f90") and C source-code files (with extensions "c" and "h"). Generally, users will not need to compile these programs; the executable files provided in the distribution can be used on computers that run the Microsoft Windows operating system (version XP or later). For other operating systems, the programs will need to be compiled. When compiling, if the Geometric Multigrid (GMG) solver (Wilson and Naff, 2004; Banta, 2006) is to be supported, the C sourcecode files need to be compiled with a $\mathrm{C}$ compiler and all Fortran files except "nogmg.f" need to be compiled with a Fortran-90 (or later) compiler. Alternatively, the programs can be compiled using only a Fortran compiler; however, the resulting executables will not support GMG. To compile the 
programs using only a Fortran compiler, include file "nogmg.f" in the files to be compiled, and omit file "gmg7.f" and the C-language files.

\section{Acknowledgments}

Conversations with Steffen Mehl (USGS) and Mary Hill (USGS) encouraged the development of support for Local Grid Refinement (Mehl and Hill, 2005, 2007, 2010) as part of the development of the PSB capability.

\section{References Cited}

Baird, K.J., and Maddock, Thomas, III, 2005, Simulating riparian evapotranspiration-A new methodology and application for groundwater models: Journal of Hydrology v. 312, p. 176-190, accessed April 4, 2011, at http://www.sciencedirect.com.

Banta, E.R., 2000, MODFLOW-2000, the U.S. Geological Survey modular ground-water modelDocumentation of packages for simulating evapotranspiration with a segmented function (ETS1) and drains with return flow (DRT1): U.S. Geological Survey Open-File Report 00-466, 127 p. (Also available at http://pubs.er.usgs.gov/pubs/ofr/ofr00466.)

Banta, E.R., 2006, Modifications to MODFLOW boundary conditions and an adaptive-damping scheme for Picard iterations for a highly nonlinear regional model, in MODFLOW and more 2006-Managing ground water systems, Golden, Colo., 2006, Proceedings: Golden, Colo., International Ground Water Modeling Center and Colorado School of Mines, p. 596-600.

Colorado Water Conservation Board and Colorado Division of Water Resources, 2005, Colorado's Decision Support Systems: Denver, Colo., Colorado Division of Water Resources, accessed April 4, 2011, at http://cdss.state.co.us/DNN/default.aspxx.

Danskin, W.R., McPherson, K.R., and Woolfenden, L.R., 2006, Hydrology, description of computer models, and evaluation of selected water-management alternatives in the San Bernardino area, California: U.S. Geological Survey Open-File Report 2005-1278, 178 p. (Also available at http://pubs.usgs.gov/of/2005/1278/.)

Doherty, John, 2010, PEST model-independent parameter estimation user manual (5th ed.): [Brisbane, Australia], Watermark Numerical Computing, variously paginated, available on April 13, 2011, at http://www.pesthomepage.org/Downloads.php.

Harbaugh, A.W., 1990, A computer program for calculating subregional water budgets using results from the U.S. Geological Survey modular three-dimensional finite-difference groundwater model: U.S. Geological Survey Open-File Report 90-392, 46 p. (Also available online at http://water.usgs.gov/nrp/gwsoftware/zonebud3/ofr90392.pdf.)

Harbaugh, A.W., 2005, MODFLOW-2005, the U.S. Geological Survey modular ground-water model-The ground-water flow process: U.S. Geological Survey Techniques and Methods, book 6, chap. A16, variously paginated. (Also available at http://pubs.er.usgs.gov/usgspubs/tm/tm6A16.)

Harbaugh, A.W., Banta, E.R., Hill, M.C., and McDonald, M.G., 2000, MODFLOW-2000, the U.S. Geological Survey modular ground-water model-User guide to modularization concepts and the Ground-Water Flow Process: U.S. Geological Survey Open-File Report 00-92, 121 p. (Also available at http://water.usgs.gov/nrp/gwsoftware/modflow2000/ofr00-92.pdf.)

Harbaugh, A.W., and Hill, M.C., 2009, Observations in MODFLOW-2005-File OBS.pdf distributed with MODFLOW-2005: U.S. Geological Survey, 32 p. (Also available at http://water.usgs.gov/nrp/gwsoftware/modflow2005/modflow2005.html.) 
Hill, M.C., Banta, E.R., Harbaugh, A.W., and Anderman, E.R., 2000, MODFLOW-2000, the U.S. Geological Survey modular ground-water model-User guide to the Observation, Sensitivity, and Parameter-Estimation Processes and three post-processing programs: U.S. Geological Survey Open-File Report 00-184, 209 p. (Also available at http://water.usgs.gov/nrp/gwsoftware/modflow2000/ofr00-184.pdf.)

Maddock, Thomas, III, and Baird, K.J., 2002, A riparian evapotranspiration package for MODFLOW-96 and MODFLOW-2000: Tucson, Ariz., University of Arizona Research Laboratory for Riparian Studies, HWR No. 02-030, 50 p.

Mehl, S.W., and Hill, M.C., 2005, MODFLOW-2005, The U.S. Geological Survey modular ground-water model-Documentation of shared node Local Grid Refinement (LGR) and the Boundary Flow and Head (BFH) Package: U.S. Geological Survey Techniques and Methods, book 6, chap. A12, 68 p. (Also available at http://water.usgs.gov/nrp/gwsoftware/modflow2005_lgr/mflgr.html.)

Mehl, S.W., and Hill, M.C., 2007, MODFLOW-2005, The U.S. Geological Survey modular ground-water model-Documentation of the Multiple-Refined-Areas capability of Local Grid Refinement (LGR) and the Boundary Flow and Head (BFH) Package: U.S. Geological Survey Techniques and Methods, book 6, chap. A21, 13 p. (Also available at http://pubs.usgs.gov/tm/2007/06A21/.)

Mehl, S.W., and Hill, M.C., 2010, MODFLOW-LGR-Modifications to the Streamflow-Routing Package (SFR2) to route streamflow through locally refined grids: U.S. Geological Survey Techniques and Methods, book 6, chap. A34, 15 p. (Also available at http://water.usgs.gov/nrp/gwsoftware/modflow2005_lgr/tm6a34.pdf.)

Poeter, E.P., Hill, M.C., Banta, E.R., Mehl, Steffen, and Christensen, Steen, 2005, UCODE_ 2005 and six other computer codes for universal sensitivity analysis, calibration, and uncertainty evaluation constructed using the JUPITER API: U.S. Geological Survey Techniques and Methods, book 6, chap. A11, 283 p. (Also available at http://pubs.er.usgs.gov/usgspubs/tm/tm6A11.)

Wilson, J.D., and Naff, R.L., 2004, MODFLOW-2000, The U.S. Geological Survey modular ground-water model-GMG linear equation solver package documentation: U.S. Geological Survey Open-File Report 2004-1261, 47 p., available only online at http://pubs.water.usgs.gov/ofr2004-1261.

Winston, R.B., 2000, Graphical User Interface for MODFLOW, version 4: U.S. Geological Survey Open-File Report 00-315, 27 p. (Also available at http://water.usgs.gov/nrp/gwsoftware/mfgui4/modflow-gui.html.)

Yager, R.M., 2004, Effects of model sensitivity and nonlinearity on nonlinear regression of ground water flow: Ground Water, v. 42, no. 3, p. 390-400. 


\section{Appendix 1: Programmer Documentation for the Partition Stress Boundaries Capability}

This appendix documents programming aspects of the Partition Stress Boundaries (PSB) capability of MODFLOW-CDSS and MODFLOW-LGR-CDSS. Much of the discussion presented here assumes that the reader is familiar with chapter 9 in Harbaugh (2005), which provides programmer documentation of MODFLOW-2005, and with Local Grid Refinement (LGR, Mehl and Hill, 2005, 2007, 2010). Source code for the PSB capability is in file psb1.f90, which is included in the distribution file available for download from the URL listed in the Preface of this report.

The PSB capability takes advantage of the Fortran modules, derived types, and module arrays on which LGR is based. In MODFLOW-2005 (Harbaugh, 2005) and MODFLOW-LGR (Mehl and Hill, 2005, 2007, 2010), each of the stress packages defines an array of elements of a derived type designed to hold all variable and array data needed for the package. When LGR is used, each derived-type element in the array contains data corresponding to either the parent grid or one of the child grids. The PSB capability uses these derived-type arrays, but when PSB is used, each element in the array corresponds to one partition instead of one grid. When PSB and LGR are used in the same simulation, each element in the array corresponds to one partition in either the parent grid or one of the child grids. Multiple partitions can be defined for any of the grids. PSB keeps track of the assignment of partitions to grids according to the contents of each name file.

When either MODFLOW-CDSS or MODFLOW-LGR-CDSS is invoked, the name file (or each name file, when MODFLOW-LGR-CDSS is used) is read by PSB. If multiple input files for any supported stress package are listed, PSB is activated and takes over processing of that package. PSB stores the input file name and unit number for each partition listed in the name file and assigns the IUNIT element for that package as zero. From then on, all subroutine calls for that package are handled by PSB. The source code for the stress packages is unchanged except that the TEXT variables of the Budget-Procedure subroutines are defined as public module variables. PSB makes all calls to subroutines of packages for which partitions have been defined. Prior to calling the subroutines of the Budget Procedure, PSB assigns TEXT as the user-specified (or default) identifier for each partition. Otherwise, all calculations and assignments required to simulate the stress boundaries and observations are handled by the stress-package subroutines as programmed in MODFLOW-2005 and documented by Harbaugh (2005), Banta (2000), or Harbaugh and Hill (2009). 
For all stress packages, PSB stores data needed to keep track of partitions in each grid in an array named PARTITIONS. PARTITIONS is an array of elements of derived type PARTITION. Each structure of type PARTITION stores information about one partition. Derived type PARTITION is defined as follows:

\begin{tabular}{|ll|}
\hline TYPE PARTITION & \\
CHARACTER(LEN=4) & $:$ : PACKAGE \\
CHARACTER(LEN=16) & $:$ ID \\
INTEGER & $::$ UNIT \\
INTEGER & $::$ PKGINDEX \\
END TYPE PARTITION & \\
\hline
\end{tabular}

where:

PACKAGE is the three- or four-letter file type used in the name file to activate a package.

PACKAGE may be any of "DRN," "DRT," "EVT," "ETS," “GHB," "RCH,” "RIV,"

"WEL," "DROB," "GBOB," or "RVOB." See table 1 for packages and file types,

ID is the partition identifier, as assigned by the user in the name file or by default,

UNIT is the unit number assigned to the partition in the name file, and

PKGINDEX is an integer whose value points to the element in the derived-type module array belonging to the package identified by PACKAGE. For example, if PACKAGE is "RIV" and PKGINDEX equals 2, data for the partition referenced by the structure of type PARTITION are stored in element 2 of the GWFRIVDAT array of the River Package.

The module that implements the PSB capability (the "PSBMODULE" module) defines an array of elements of derived type GWFPSBDAT. Each element in this array holds a PARTITIONS array and several scalar variables needed for one grid. This organization allows PSB to maintain correct correspondence between partitions and grids. Note that in a given package module, all partitions in all grids are stored in the module array (for example, the GWFRIVDAT array in the River Package). The assignment of partitions to grids is encapsulated in the GWFPSBDAT arrays and the PKGINDEX components of elements in the PARTITIONS arrays.

The PSB capability is implemented by eight subroutines called from the main program unit of either MODFLOW-CDSS or MODFLOW-LGR-CDSS. PSB subroutines associated with 
MODFLOW procedures (for example, the Allocate and Read Procedure, the Read and Prepare Procedure, and so on) are called along with calls to the packages' subroutines of that procedure. The PSB subroutines called from the main program units are summarized in table 1-1.

Table 1-1. Subroutines of the Partition Stress Boundaries capability.

\begin{tabular}{|l|l|}
\hline \multicolumn{1}{|c|}{$\begin{array}{c}\text { Subroutine } \\
\text { name }\end{array}$} & \multicolumn{1}{c|}{ Description } \\
\hline PSB1SETUP & $\begin{array}{l}\text { Determine need for partitions in each package, for all grids. If any package is } \\
\text { partitioned in any grid, allocate and initialize the PARTITIONS arrays with sufficient } \\
\text { space to handle that package in all grids. }\end{array}$ \\
\hline PSB1AR & $\begin{array}{l}\text { Write indication that PSB is active for current grid and table of partitions to listing } \\
\text { file. Call Allocate and Read Procedure (AR) subroutines for all partitions in current } \\
\text { grid. Set IUNIT element to 0 for any package that is to be handled by PSB. }\end{array}$ \\
\hline GWF2PSB1RP & $\begin{array}{l}\text { Call Read and Prepare Procedure (RP) subroutines of the Groundwater-Flow Process } \\
\text { for all partitions in current grid. }\end{array}$ \\
\hline GWF2PSB1FM & Call Formulate Procedure (FM) subroutines for all partitions in current grid. \\
\hline GWF2PSB1BD & $\begin{array}{l}\text { For each partition in the current grid, assign TEXT module variable as the ID } \\
\text { component for the partition, then call the Budget Procedure (BD) subroutine } \\
\text { appropriate for the partition. }\end{array}$ \\
\hline OBS2PSB1SE & $\begin{array}{l}\text { Call Simulated Equivalents Procedure (SE) subroutines for observations associated } \\
\text { with partitions in current grid. }\end{array}$ \\
\hline OBS2PSB1OT & $\begin{array}{l}\text { Call Output Procedure (OT) subroutines for observations associated with partitions } \\
\text { in current grid. }\end{array}$ \\
\hline PSB1DA & $\begin{array}{l}\text { Call Deallocate Procedure (DA) subroutines for all partitions in current grid. } \\
\text { Deallocate memory allocated by the PSB module for the current grid. }\end{array}$ \\
\hline
\end{tabular}




\section{Appendix 2: Partition Stress Boundaries Example}

An example demonstrating the use of the Partition Stress Boundaries (PSB) capability is included in the distribution file available at the URL listed in the Preface of this report. Figure 2-1 is a map view of the hypothetical groundwater system simulated in the example. The model domain represents a two-layer aquifer system in a square area 18,000 meters on a side. The site encompasses three rivers, a hillside that is the source of a small influx of groundwater, two wells, and an irrigated corn field. Recharge from precipitation is simulated over the entire area. Additional recharge comes from excess irrigation water applied to the corn field. An initial steadystate stress period simulates conditions prior to withdrawal of groundwater from the wells. Four transient-state stress periods simulate response of the system to constant pumping from the wells over 283 days. The input files for this example, which contain additional details of this hypothetical system, are in the test-run $\backslash p s b$ directory of the MODFLOW-CDSS distribution.

The name file for this example is shown in figure 2-2. Note that the name file lists two input files of type $\mathrm{RCH}$ (Recharge Package), one representing recharge from precipitation and one representing recharge due to excess irrigation water. Two files of type WEL (Well Package) are listed, one for each well. Three files of type RIV (River Package), one for each river, are listed. Also note that the entries of type RVOB (River-Package observations) include the partition identifier of the River-Package partition that defines the river cells to which the observations specified in each RVOB file apply. Each of the RCH, WEL, and RIV input files is constructed according to instructions provided in Harbaugh (2005); no special entries are required in these files to use PSB.

Selected output of the listing file, showing the table of stress-boundary partitions and a volumetric water-budget table, is shown in figure 2-3. Volumetric water-budget data for all time steps, saved to a binary cell-by-cell flow file and extracted using GW_Chart (Winston, 2000), illustrate (fig. 2-4) that the various partitioned components of the volumetric water budget are individually tracked and readily distinguished for interpretation. 
COLUMN

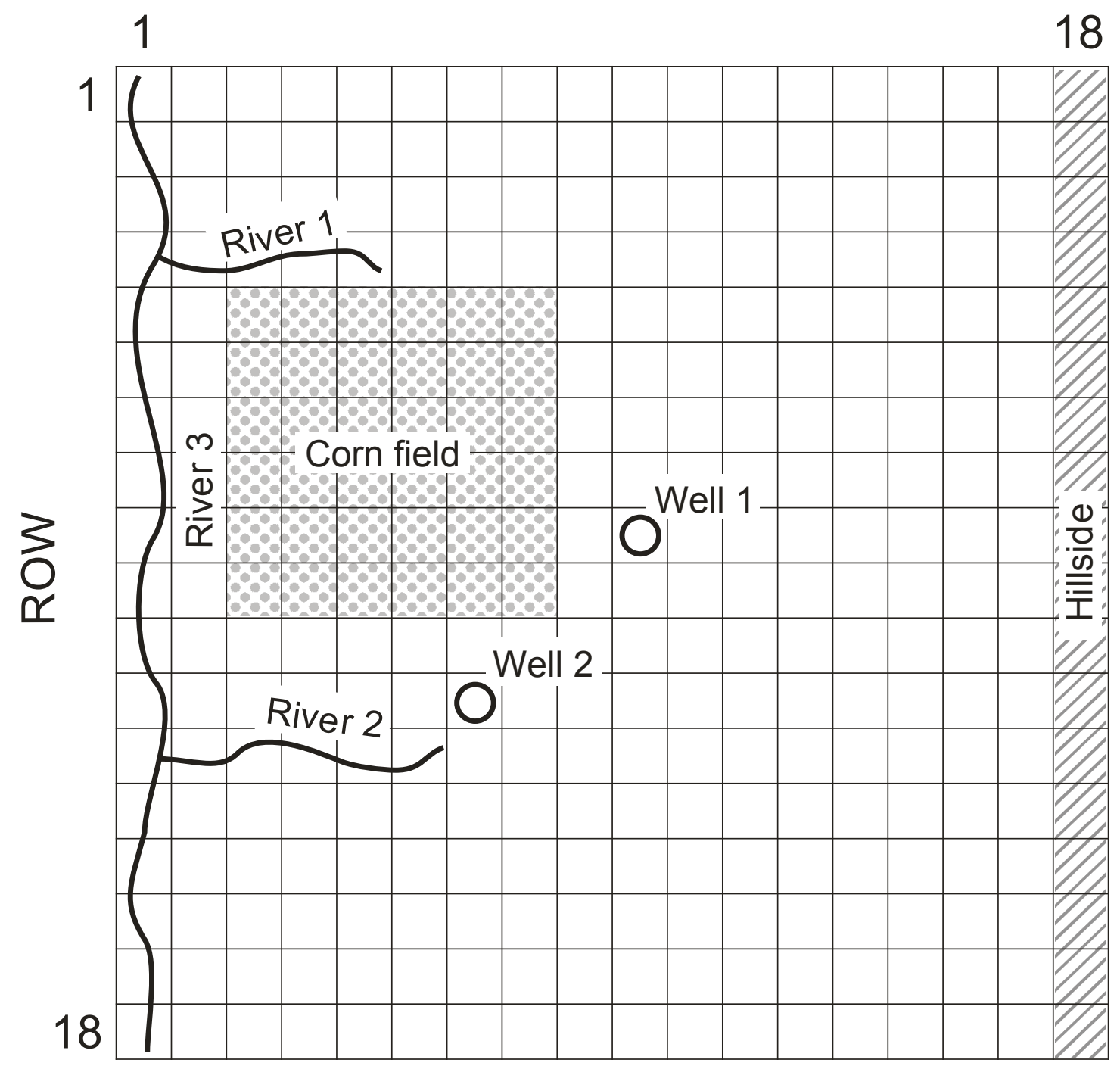

Figure 2-1. Model grid and features for the Partition Stress Boundaries example. 


\begin{tabular}{|c|c|c|c|}
\hline \multicolumn{4}{|c|}{ \# Name file for test case psb } \\
\hline \multicolumn{4}{|c|}{ \# } \\
\hline \multicolumn{4}{|c|}{ \# Output files } \\
\hline list & 12 & \multicolumn{2}{|l|}{ psb.lst } \\
\hline data & 13 & \multicolumn{2}{|l|}{ psb._simhds } \\
\hline data & 14 & \multirow{2}{*}{\multicolumn{2}{|c|}{ psb._simriv }} \\
\hline \multicolumn{2}{|l|}{ \# } & & \\
\hline \multicolumn{4}{|c|}{ \# Global input files } \\
\hline dis & 31 & \multicolumn{2}{|l|}{ psb.dis } \\
\hline zone & 32 & \multicolumn{2}{|l|}{ psb.zon } \\
\hline mult & 33 & \multicolumn{2}{|l|}{ psb.mlt } \\
\hline \multicolumn{4}{|l|}{$\#$} \\
\hline \multicolumn{4}{|c|}{ \# Flow process input files } \\
\hline bas 6 & 41 & \multicolumn{2}{|l|}{ psb.bas } \\
\hline $\operatorname{lpf}$ & 42 & \multicolumn{2}{|l|}{ psb.lpf } \\
\hline pcg & 44 & \multicolumn{2}{|l|}{ psb.pcg } \\
\hline oc & 45 & \multicolumn{2}{|l|}{ psb.oc } \\
\hline ghb & 46 & \multicolumn{2}{|l|}{ psb.ghb } \\
\hline \multicolumn{4}{|l|}{ \# } \\
\hline \multicolumn{4}{|c|}{ ed stress-boundary packages } \\
\hline rch & 48 & psb.rch & RCH_Precip \\
\hline rch & 49 & \multicolumn{2}{|c|}{ psb.rchcorn "RCH: Corn irrig" } \\
\hline wel & 43 & \\
\hline wel & 50 & \multicolumn{2}{|l|}{ psb.wel2 } \\
\hline riv & 51 & psb.riv1 & "River 1" \\
\hline riv & 52 & psb.riv2 & "River 2" \\
\hline riv & 53 & psb.riv3 & "River 3" \\
\hline \multicolumn{4}{|l|}{ \# } \\
\hline \# Obs & nput & \multicolumn{2}{|l|}{ files } \\
\hline & 22 & psb.ohd & \\
\hline rvob & 23 & psb.orv & "River 3" \\
\hline rvob & 24 & psb2.orv & "River 2" \\
\hline
\end{tabular}

Figure 2-2. Name file for the Partition Stress Boundaries example. 


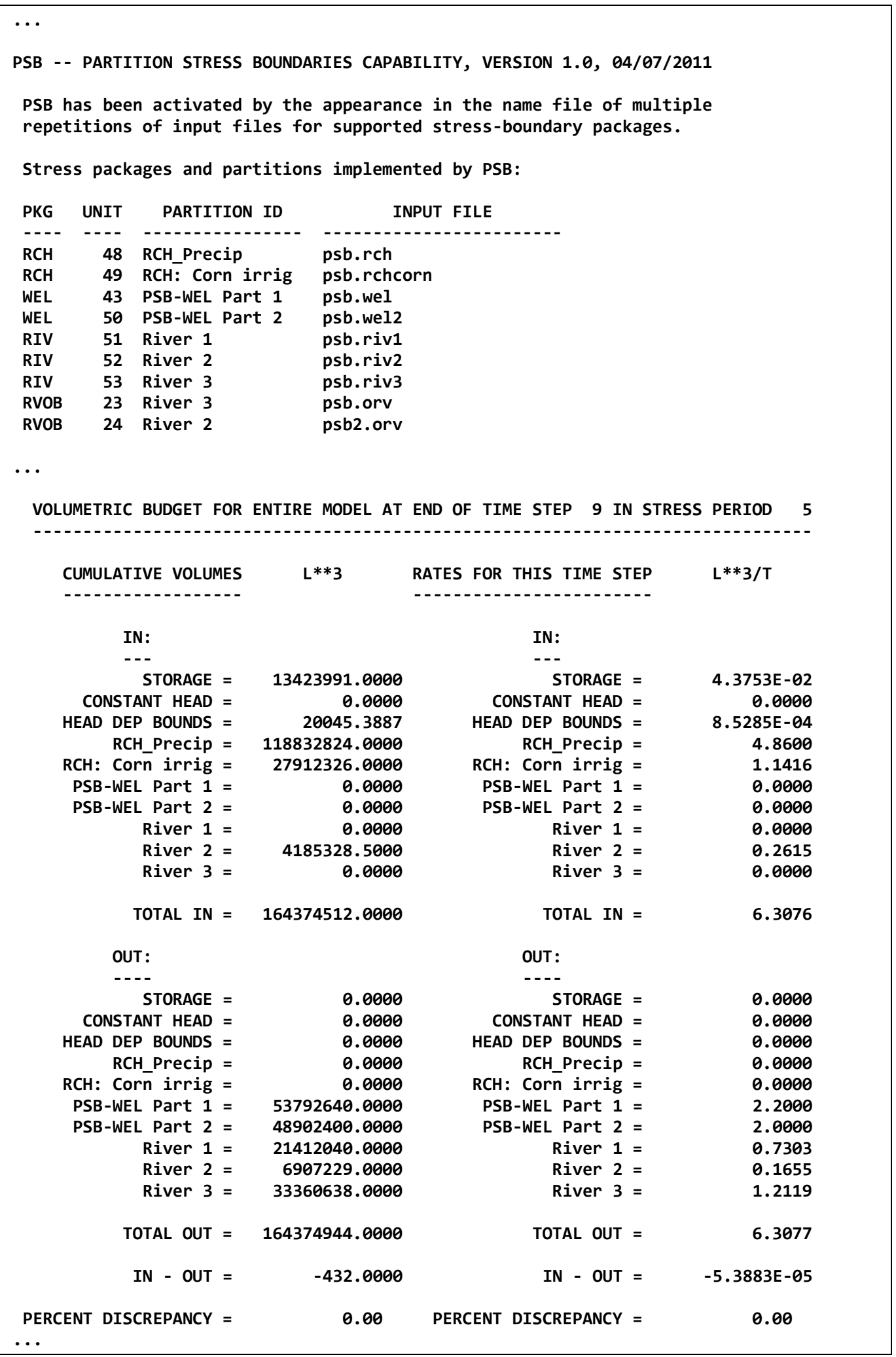

Figure 2-3. Selected output for the Partition Stress Boundaries example. 


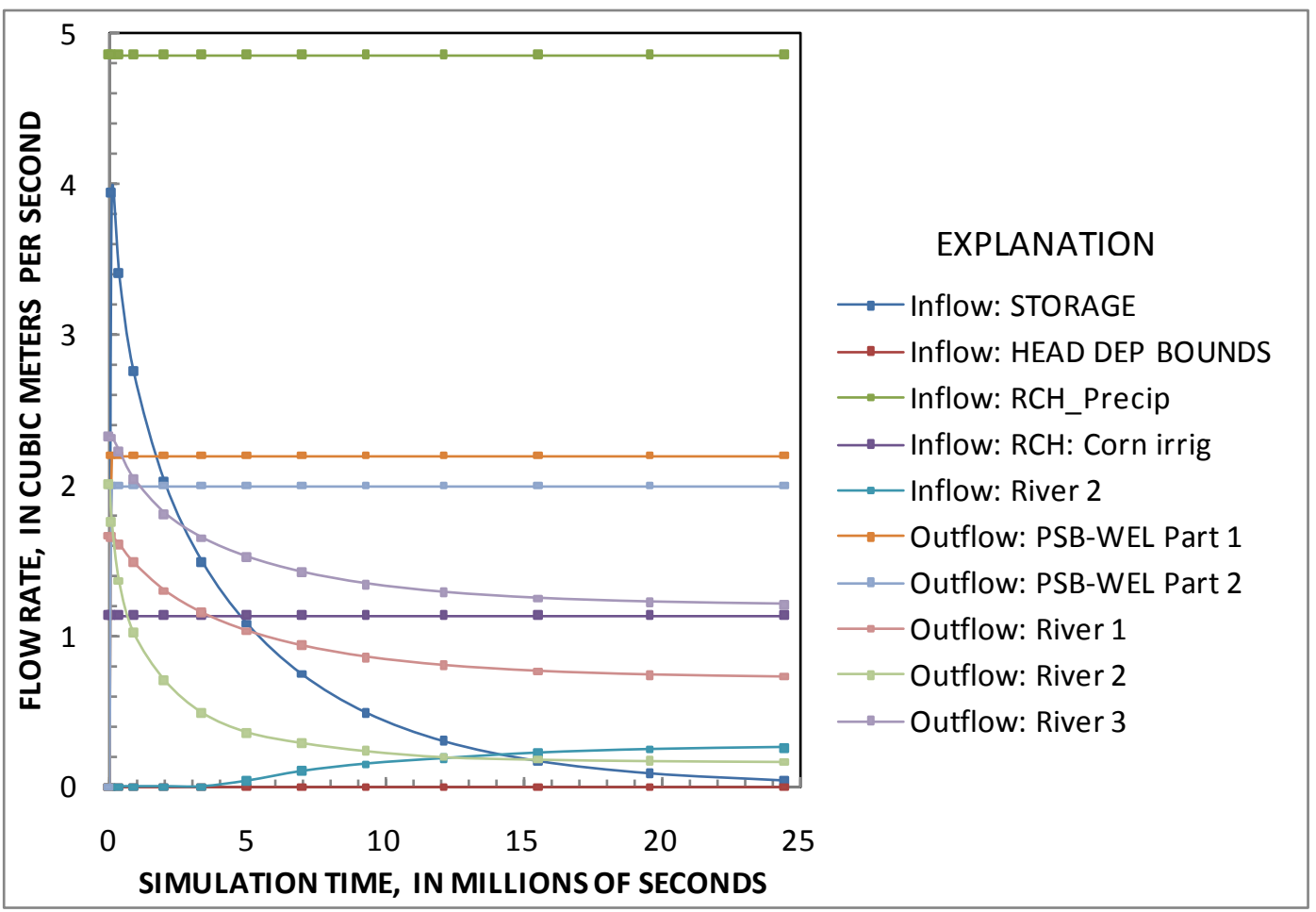

Figure 2-4. Volumetric flow rates for water-budget components of the Partition Stress Boundaries example.

Publishing support provided by:

Denver Publishing Service Center

For more information concerning this publication, contact:

Director, USGS Colorado Water Science Center

Box 25046, Mail Stop 415

Denver, CO 80225

(303) 236-4882

Or visit the Colorado Water Science Center Web site at:

http://co.water.usgs.gov/ 